\title{
鋼構造露出柱脚に適用する鋼管型ダンパー開発のための基礎的研究 FUNDAMENTAL STUDY FOR DEVELOPMENT OF TUBULAR DAMPERS FOR USE IN EXPOSED-TYPE COLUMN BASE OF STEEL MOMENT FRAMES
}

\author{
向出静 司*1, 井本大貴 ${ }^{* 2}$, 長山暢宏*3 \\ Seiji MUKAIDE, Daiki IMOTO and Nobuhiro NAGAYAMA
}

\begin{abstract}
In order to adapt to anchor bolts of exposed bases in steel moment frames, we propose a hysteretic damper of tubular shaped steel for use in a bolt joint. The damper is expected to deform stably over a large plastic deformation range after local buckling occurs in the tubular part. The present paper describes axial loading tests of the elemental dampers and cyclic loading tests of exposed bases with the dampers for purpose of development of the new device. The test results reveal the technical viability and optimal design condition.
\end{abstract}

Keywords : hysteretic damper, radius thickness ratio, deformation capacity, local buckling 履歴型ダンパー, 径厚比, 変形性能, 局部座屈

1. はじめに

近年，建物の耐震安全性を高めるために，制振構造を採用する例 が増加する傾向にあり，とりわけ超高層鋼構造建物では一般的な技 術となりつつある。中低層建物においても，エネルギーの釣合いに 基づく耐震計算法の制定を契機として，さらなる利用拡大が期待さ れている.

パッシブ型の制振構造では，エネルギー吸収部材により建築物の 主要構造全体の塑性変形を緩和することができるが，一定の剛性を 付与しつつ大地震時に最下層柱下端や柱脚部を弾性に保つことは難 しい.これらの位置で塑性化した場合, 大地震後の修復は困難である. このような問題に対し，柱脚部に適用できるダンパーが有効な解決 策となり得る。また，柱脚部のダンパーを積極的にエネルギー吸収 させることで，上部構造の損傷を低減させる効果も期待できる ${ }^{11}$.

柱脚部に適用する履歴型ダンパーの研究事例としては，浮き上が り降伏ベースプレートにより柱脚の浮き上がりを許容しつつ履歴ダ ンパーとして機能させる工法 ${ }^{2), 3)}$ な゙やセルフセンタリング機能を持 つダンパーによりエネルギーを吸収させる工法 ${ }^{4)}$ が挙げられる。前 者は, 浮き上がりを伴うため高度な設計手法を必要とし, 後者はエ ネルギー吸収性能が低いなどの課題があり，鋼構造骨組の柱脚部に 適用するためのダンパーとしては, 利用しやすい形で実用化されて いないのが現状である、本研究では，筆者が提案する露出柱脚に適 用するための鋼管型のダンパーを開発するための基礎的な検討を行 う.

本システムでは，図1(a)に示すように，アンカーボルトの外側に 挿入された円形鋼管状のダンパー（以下，単に鋼管ダンパーと称す）
が，ナットおよびベースプレートの両方に接合されることで構成さ れる，本システムを適用する際の想定ディテールの例を図 2 に示す。 同図のように，溶接接合あるいはねじ接合により，鋼管ダンパーの 両端を接合することで，圧縮力だけではなく，引張力を伝達させる ことができる。一般に，柱脚には曲げモーメントが卓越して作用し， これに対して，図1(b)に示すように，曲げ引張側鋼管ダンパーには 圧縮力が，曲げ圧縮側鋼管ダンパーには引張力が作用する，曲げ圧 縮側および曲げ引張側の鋼管ダンパーが先行して繰り返し塑性変形 することにより地震エネルギーを吸収し，鉄骨柱・アンカーボルト・ ベースプレートを弾性に保つ。この際，アンカーボルト降伏型の場 合に見られるようなスリップ挙動を示さず，大きなエネルギー吸収 を期待できる，また，ねじ接合する場合（図 2(c)）には，地震後の 補修を容易に行えるというメリットも併せ持つ。なお，ダンパーと は称してないものの，本工法と類似の研究事例として，端部は接合 せずにアンカーボルトに鋼管を挿入する工法 ${ }^{5)}$ がある。同工法では 鋼管端部を接合しないためスリップ挙動を示し，大きなエネルギー 吸収を期待できない.

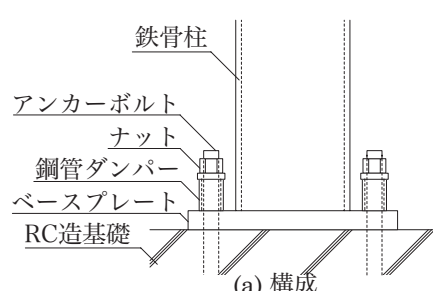

(a) 構成

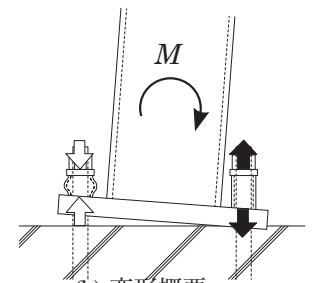

(b) 変形概要
図 1 鋼管ダンパーの構成と変形概要

\footnotetext{
本論の一部は, 日本建築学会大会学術講演梗概集 (2008 2011年) および日本建築学会近畿支部研究発表会 (2008 2011年)に発表している。

*1 大阪大学大学院工学研究科地球総合工学専攻～Assist. Prof., Div. of Global Architecture, Graduate School of Eng., Osaka Univ., Dr. Eng. 助教・博士 (工学)

* 2 九州電力

(元 大阪大学大学院 大学院生)

*3 大阪大学大学院工学研究科地球総合工学専攻 大学院生 
本システムのように，主として軸力が作用する鋼管状のダンパー を利用するためには, 軸方向の大きな塑性変形に伴って顕著な局部 座屈が生じることも許容しなければならない，さらに，柱脚には曲 げモーメントだけではなく，せん断力や柱軸力が作用する。せん断 力がベースプレート下面の摩擦力で抵抗できないと, 鋼管ダンパー もせん断力を負担し, 軸変形のみならず曲げせん断変形が生じる. また，柱軸力によっては，鋼管ダンパーの軸変形が変動する上， ベー スプレート下面の摩擦力も変動する。このように，鋼管ダンパーは 複雑な塑性変形性状を示すと予想される。そこで, 径厚比が小さい 断面の鋼管ダンパーを対象とした実験を通して, 本工法が履歴型ダ ンパーとしての性能を有しているか基礎的な検証を行うことが本論 の目的である，本論では，まず，鋼管ダンパー単体の軸方向載荷に より, 大変形域での履歴性状や変形性能を実験的に検討するととも に, より高い変形性能を得るための設計条件を検討する.さらに, 鋼管ダンパーを適用した際の露出柱脚の載荷実験により，その構造 性能を把握する。

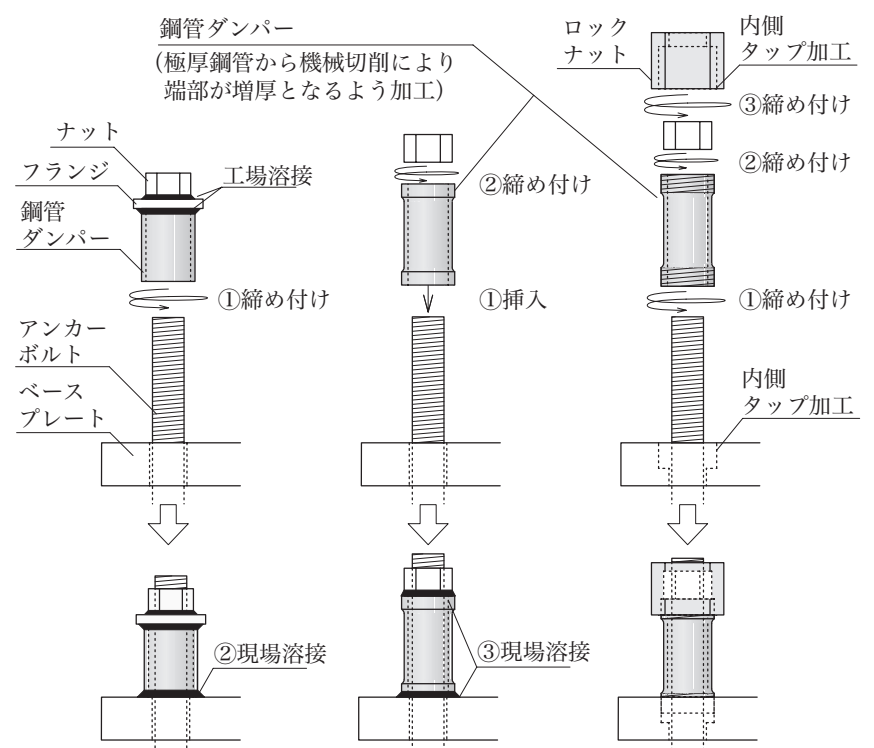

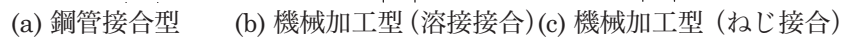
図 2 露出柱脚に適用する鋼管ダンパー

\begin{tabular}{|c|c|c|c|c|}
\hline 種類 & \multicolumn{3}{|c|}{ 鋼管溶接型試験体 (DW) } & 機械加工型試験体 (DM) \\
\hline \multirow[t]{2}{*}{ 溶接 } & 完全溶 ～～～～ & 込溶接 & 隅肉溶接 & \multirow[b]{2}{*}{ - } \\
\hline & $\begin{array}{c}\text { 仕上げ無 } \\
(\mathrm{G})\end{array}$ & $\begin{array}{c}\text { 仕上げ有 } \\
(\mathrm{GM})\end{array}$ & $\begin{array}{l}\text { 無 } \\
\text { (F) }\end{array}$ & \\
\hline
\end{tabular}

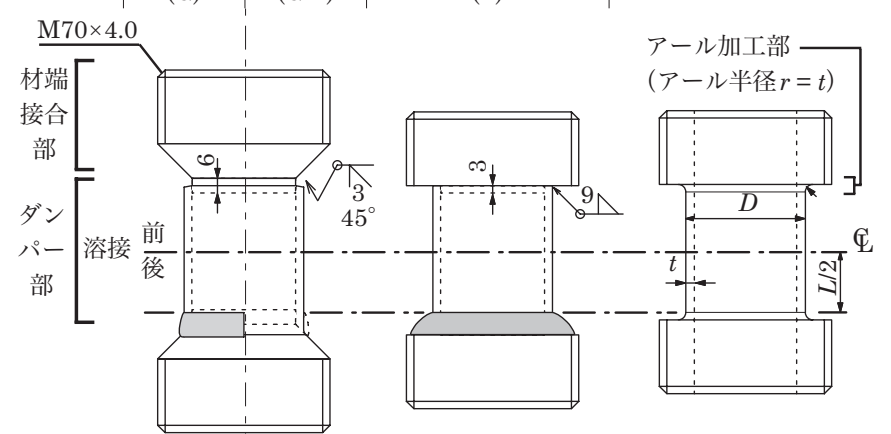

試験体名称例：DW17-0.75-G

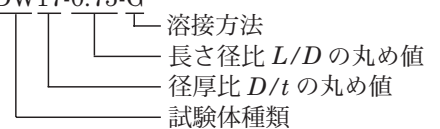

図 3 軸方向載荷実験試験体の概要

\section{2. 鋼管ダンパーの軸方向載荷実験}

\section{1 実験パラメータおよび試験体}

本章では，正負交番繰返軸方向載荷実験により，鋼管ダンパーを 大変形域まで塑性変形させた時の構造性能について検討する、鋼管 ダンパーの試験体の概要を図 3 に示す。試験体は，塑性変形が生じ るダンパー部と治具に接合するための材端接合部からなり，両者を 溶接接合した試験体（以下，鋼管溶接型試験体）および，極厚鋼管 から機械加工により切削することで材端接合部がダンパー部と一体 となるよう製作された試験体（以降，機械加工型試験体）の 2 種類 を設定する。両者の実験は，以下のように計画する．

○鋼管溶接型試験体（DW シリーズ）：試験体一覧を表 1 に示す。パ ラメータとしてダンパー部の径厚比 $D / t(D:$ 外径, $t$ : 板厚 $)$ およ び長さ $L$ に加え，溶接方法を変化させた試験体を設定する，溶接方 法は，完全溶込溶接で溶接余盛部をそのまま残すもの $(\mathrm{G})$ と機械切 削により平滑に加工したもの $(\mathrm{GM})$ と隅肉溶接 $(\mathrm{F})$ の計 3 種類を設定 する。溶接部の機械切削は，溶接余盛による断面積の急激な変化を 緩和し，同部の歪集中を避けるためである。なお，材端接合部には

表 1 試験体一覧（DW シリーズ）

\begin{tabular}{|c|c|c|c|c|}
\hline \multirow{2}{*}{ 試験体 } & \multicolumn{2}{|c|}{ 断面寸法 (径厚比 $D / t$ ) } & \multirow{2}{*}{$\begin{array}{c}\text { 長さ } \\
L(\mathrm{~mm})\end{array}$} & \multirow{2}{*}{$\begin{array}{l}\text { 溶接 } \\
\text { 詳細 }\end{array}$} \\
\hline & 公称値 & 実測値 & & \\
\hline DW17-0.75-G & \multirow{8}{*}{$\begin{array}{c}\phi 48.6 \times 3.2 \\
\quad(15.2)\end{array}$} & \multirow{8}{*}{$\begin{array}{c}\phi 48.6 \times 2.9 \\
(16.8)\end{array}$} & 30 & G \\
\hline DW17-0.75-GM & & & 31 & GM \\
\hline DW17-0.75-F & & & 36 & $\mathrm{~F}$ \\
\hline DW17-1.00-G & & & 45 & G \\
\hline DW17-1.00-GM & & & 43 & GM \\
\hline DW17-1.00-F & & & 49 & $\mathrm{~F}$ \\
\hline DW17-1.25-G & & & 58 & G \\
\hline DW17-1.50-G & & & 69 & G \\
\hline DW10-1.00-G & \multirow{2}{*}{$\begin{array}{c}\phi 48.6 \times 5.1 \\
(9.5)\end{array}$} & \multirow{2}{*}{$\begin{array}{c}\phi 48.6 \times 4.9 \\
(9.9)\end{array}$} & 39 & $\mathrm{G}$ \\
\hline DW10-1.25-G & & & 50 & G \\
\hline
\end{tabular}

\begin{tabular}{|c|c|c|}
\hline 試験体名 & $\begin{array}{c}\text { 断面寸法 } \\
\text { (径厚比 } D / t \text { ) }\end{array}$ & $\begin{array}{c}\text { 長さ } \\
L(\mathrm{~mm}) \\
\end{array}$ \\
\hline DM17-0.75 & \multirow{3}{*}{$\begin{array}{c}\phi 48.6 \times 2.9 \\
\quad(16.8)\end{array}$} & 36 \\
\hline DM17-1.0 & & 49 \\
\hline DM17-1.25 & & 61 \\
\hline DM12-0.6 & \multirow{7}{*}{$\begin{array}{c}\phi 48.6 \times 4.0 \\
(12.2)\end{array}$} & 29 \\
\hline DM12-0.7 & & 34 \\
\hline DM12-0.8 & & 39 \\
\hline DM12-0.9 & & 44 \\
\hline \begin{tabular}{|l|} 
DM12-1.0 \\
\end{tabular} & & 49 \\
\hline DM12-1.1 & & 54 \\
\hline DM12-1.2 & & 59 \\
\hline DM10-0.7 & \multirow{7}{*}{$\begin{array}{c}\phi 48.6 \times 4.9 \\
(9.9)\end{array}$} & 34 \\
\hline DM10-0.8 & & 39 \\
\hline DM10-0.9 & & 44 \\
\hline DM10-1.0 & & 49 \\
\hline DM10-1.1 & & 54 \\
\hline DM10-1.2 & & 59 \\
\hline DM10-1.3 & & 63 \\
\hline DM8-0.8 & \multirow{10}{*}{$\begin{array}{c}\phi 48.6 \times 6.0 \\
(8.1)\end{array}$} & 39 \\
\hline DM8-0.9 & & 44 \\
\hline DM8-1.0 & & 49 \\
\hline \begin{tabular}{|l|} 
DM8-1.1 \\
\end{tabular} & & 54 \\
\hline DM8-1.2 & & 59 \\
\hline DM8-1.4 & & 69 \\
\hline DM8-1.6 & & 78 \\
\hline DM8-1.8 & & 88 \\
\hline DM8-2.0 & & 98 \\
\hline DM8-2.2 & & 108 \\
\hline
\end{tabular}


開先と裏当て金が一体となるよう凸型の突起を持たせており， $3 \mathrm{~mm}$ 程度を鋼管内に飲み込ませている。

$\bigcirc$ 機械加工型試験体（DM シリーズ）：試験体一覧を表 2 に示す。ダ ンパー部の径厚比 $D / t$ および長さ $L$ をW シリーズと比べて細かい 刻みで設定する。機械加工試験体では, ダンパー部と材端接合部の 境界での急激な断面変化による歪集中を緩和するため，両者の間に アール加工を施している.

ダンパー部の長さ $L$ は，等厚となる部分のみの長さを指し，溶接 接合試験体では溶接部を除く長さを測定した值，機械加工試験体で はアール加工部を除いた鋼管部の長さとする.

材質は，溶接接合試験体の鋼管部については，径厚比の公称值が 15.2 および 9.5 の鋼管で，それぞれ一般構造用炭素鋼管 (STK400), 圧力配管用炭素鋼管 (STPG370) を用いる. STPG370 は, 所要の 寸法を確保しつつ, STK400 よりも高い伸び性能を持つものとし て採用している，機械加工試験体については機械構造用炭素鋼管 (STKM13A)の $\phi 76.3 \times 25$ から機械切削により製作する．材料の引 張試験結果を表 3 に示す.

\section{2 載荷方法}

図 4 に示すように，オイルジャッキにより軸方向の正負交番繰り 返し載荷を行う。オイルジャッキは軸方向のみに変形を与えるよう リニアスライダーにより拘束されている.

載荷履歴を図 5 に示す。軸力 $P$ および軸方向変形 $\delta$ は, 圧縮方向 を正と定義する，柱脚が曲げモーメントを受け変形する際，鋼管夕゙ ンパーは大きな圧縮変形を受けるとともに，ベースプレートがコン クリートへめり込むことによって僅かな引張変形を受けると想定さ れる。この状況を模擬するためにダンパーの圧縮変形と引張変形の 比を $8: 1$ と仮定し, 載荷履歴を設定している。 なお，次式の局部座 屈波長計算値 ${ }^{6} l_{b}$ を載荷履歴の目標変位の基準として用いる.

$$
l_{b}=\pi \sqrt[4]{\frac{(D \cdot t)^{2}}{3\left(1-\nu^{2}\right)}} \fallingdotseq 2.44 \sqrt{D \cdot t}
$$

ここに, $v:$ 鋼材のポアソン比 $(=0.3)$

\section{3 実験結果}

実験結果から得られた軸力 $P-$ 軸方向変形 $\delta$ 関係を図 6 , 実験結果

表 3 材料の引張試験結果

\begin{tabular}{|c|c|c|c|c|}
\hline $\begin{array}{c}\text { 断面寸法 } \\
\text { (材質） }\end{array}$ & 使用試験体 & $\begin{array}{c}\text { 降伏強さ } \\
\sigma_{y}\left(\mathrm{~N} / \mathrm{mm}^{2}\right) \\
\end{array}$ & $\begin{array}{c}\text { 引張強さ } \\
\sigma_{u}\left(\mathrm{~N} / \mathrm{mm}^{2}\right) \\
\end{array}$ & $\begin{array}{c}\text { 破断伸び } \\
(\%) \\
\end{array}$ \\
\hline \multirow{2}{*}{$\begin{array}{l}\phi 48.6 \times 3.2 \\
(\mathrm{STK} 400) \\
\end{array}$} & DW17シリーズ & 388 & 462 & $46^{* 1}$ \\
\hline & 規格值 & 235以上 & 400以上 & 23 以上: ${ }^{* 1}$ \\
\hline \multirow{2}{*}{$\begin{array}{c}\phi 48.6 \times 5.1 \\
(\mathrm{STPG} 370)\end{array}$} & DW10シリーズ & 311 & 441 & $59^{* 1}$ \\
\hline & 規格值 & 215 以上 & 370以上 & 30 以上 ${ }^{* 1}$ \\
\hline \multirow{3}{*}{$\begin{array}{c}\phi 76.3 \times 25 \\
(\mathrm{STKM} 13 \mathrm{~A})\end{array}$} & $\begin{array}{l}\text { DM17-0.75,DM17-1.0, } \\
\text { DM17-1.25,DM17-1.3 }\end{array}$ & 269 & 430 & $40^{* 2}$ \\
\hline & DMシリーズの残り全て & 269 & 451 & $41^{* 2}$ \\
\hline & 規格值 & 215 以上 & 370以上 & 30 以上 $^{* 2}$ \\
\hline
\end{tabular}

注）*1の值は 11 号試験片，*2 の值は 4 号試験片を用いたものを表す.

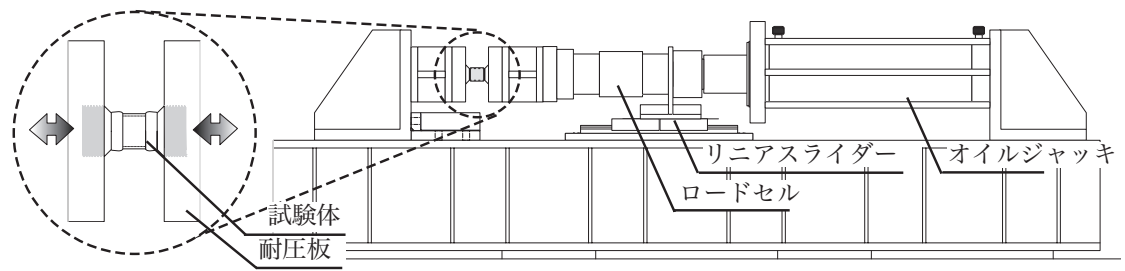

図 4 載荷装置

の一覧を表 4 に示す. で詳述する。

(a) 荷重一変形関係および破壊性状の概要

$P-\delta$ 関係の履歴ループ形状は，試験体の種別（鋼管溶接型か機械 加工型）や長さの影響があまり見られず，以下に示すように，径厚 比によってやや異なる傾向が見られる。圧縮側載荷時，引張降伏耐 力計算值 ${ }_{c} P_{y}$ と同程度の圧縮力により降伏した後, 局部座屈が発生し つつも耐力が上昇する。径厚比が小さいほど, 最大圧縮耐力 ${ }_{e} P_{\text {max }}$ ま での上昇率 ${ }_{e} P_{\text {max }} l_{\mathrm{c}} P_{y}$ は大きく, 最大耐力到達後の耐力低下が緩やか になる。引張側載荷時には, 圧縮力除荷直前と同程度の耐力で引張 降伏し, 圧縮側と正負逆向きの勾配で耐力が推移し, 最大引張耐力 ${ }_{e} P_{\text {min }}$ も最大圧縮耐力 ${ }_{e} P_{\text {max }}$ と同程度になる（すなわち, 履歴ループ が上下対称に近い形状となる)。なお，試験体が長くなるほど塑性化 後の耐力上昇が緩やかになる傾向が僅かに見られる。これは, 長く なるほど，ダンパー部に生じる平均歪度が小さくなり歪硬化が生じ にくいことが一因と考元れる。

繰り返し塑性変形が生じると, やがて試験体は引張側載荷時に急 激な耐力低下を伴う大きな亀裂が発生するか, 試験体によってはそ のまま全断面破断に至る。このような亀裂が発生した時点（図 6 中 の○, $\triangle, \diamond)$ までに, 局部座屈により耐力は低下し, 最大耐力に 対する比率が，径厚比 17 程度で $50 \sim 60 \%$ 程度, 径厚比 12 程度で $80 \%$ 程度，径厚比 10 程度で $85 \sim 95 \%$ 程度，径厚比 8 程度で $95 \%$ 前後となる，局部座屈および亀裂の発生状況については，次項以降

局部座屈を生じる円形鋼管の最大圧縮耐力計算值 ${ }_{c} P_{\text {max }}$ として以下 の実験式が提案されている ${ }^{7}$.

$$
{ }_{c} P_{\max }={ }_{c} P_{y}\left(0.0163 \frac{E \cdot t}{\sigma_{y c} \cdot D}+0.929\right)
$$

ここに, $\sigma_{y c}$ : 短柱圧縮試験から $0.2 \%$ オフセット法で求めた降伏応力 度 (本論では, 引張試験結果による実降伏応力度 $\sigma_{y}$ を用いる), $E$ : ヤング係数.この最大圧縮耐力計算值 ${ }_{c} P_{\max }$ と最大圧縮耐力実験值 ${ }_{e} P_{\text {max }}$ ・最大引張耐力実験值 ${ }_{e} P_{\text {min }}$ を比較したものを表 4 に併記する. ${ }_{c} P_{\text {max }}$ は ${ }_{e} P_{\text {max }}$ および ${ }_{e} P_{\text {min }}$ と概ね対応しているものの, (2) 式の径厚 比の検討範囲（10～39）を超えている径厚比が 8 の試験体について は，他のものよりも 1 割程度耐力が低い傾向にある.

(b) 局部座屈の発生状況

実験終了後の変形状況を写真 1 に示す。同写真より，実験終了時 の試験体の状態を見ると, 長さの変化に伴い局部座屈モードの変化 が見られる。これらは図 7 に示すように, 局部座屈が中心に 1 つ形 成される場合 (mode-Is), 非対称な局部座屈が 1 つ形成される場合 (mode-Ia), 両端に 2 つの局部座屈が形成される場合 (mode-II), の 3 種類の局部座屈モードに大別される. 分類した結果は, 表 4 に併 記している. 長さ $L$ が長くなるにつれ, mode-Is $\rightarrow$ mode-Ia $\rightarrow$ mode-

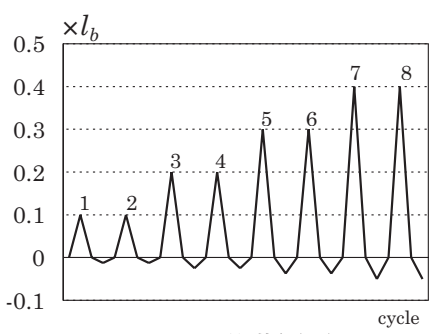

図 5 載荷履歴 
表 4 軸方向載荷実験の結果一覧

\begin{tabular}{|c|c|c|c|c|c|c|c|c|}
\hline \multirow[b]{2}{*}{ 試験体名 } & \multicolumn{3}{|c|}{ 計算値 } & \multicolumn{5}{|c|}{ 実験結果 } \\
\hline & $\frac{L}{l_{b}}$ & $\begin{array}{c}{ }_{c} P_{y} \\
(\mathrm{kN})\end{array}$ & $\frac{{ }_{c} P_{\max }}{P_{y}}$ & $\left|\frac{{ }_{e} P_{\max }}{{ }_{c} P_{\max }}\right|$ & $\left|\frac{{ }_{e} P_{\min }}{{ }_{c} P_{\max }}\right|$ & $\begin{array}{c}\text { 局部座屈 } \\
\text { モード }\end{array}$ & $\begin{array}{l}\text { 亀裂 } \\
\text { cycle }\end{array}$ & $\begin{array}{l}\text { 亀裂 } \\
\text { 位置 }\end{array}$ \\
\hline DW17-0.75-G & 1.03 & \multirow{8}{*}{162} & \multirow{8}{*}{1.44} & 0.94 & -0.98 & mode-Is & $\overline{5}$ & $\overline{\mathrm{E}}$ \\
\hline DW17-0.75-GM & 1.07 & & & 0.95 & -0.97 & mode-Is & 5 & $\mathrm{E}$ \\
\hline DW17-0.75-F & 1.24 & & & 0.95 & -0.94 & mode-Is & 4 & $\mathrm{E}$ \\
\hline DW17-1.00-G & 1.55 & & & 0.98 & -0.96 & mode-II & 4 & $\mathrm{E}$ \\
\hline DW17-1.00-GM & 1.48 & & & 0.96 & -0.90 & mode-II & 5 & $\mathrm{E}$ \\
\hline DW17-1.00-F & 1.69 & & & 0.93 & -0.90 & mode-II & 4 & $\mathrm{E}$ \\
\hline DW17-1.25-G & 2.00 & & & 0.92 & -0.89 & mode-II & 6 & $\mathrm{O}$ \\
\hline DW17-1.50-G & 2.38 & & & 0.91 & -0.88 & mode-II & 7 & $\mathrm{O}$ \\
\hline DW10-1.00-G & 1.03 & \multirow{2}{*}{209} & \multirow{2}{*}{2.01} & 0.82 & -0.83 & mode-Is & 3 & $\mathrm{E}$ \\
\hline DW10-1.25-G & 1.33 & & & 0.84 & \begin{tabular}{|l|}
-0.85 \\
\end{tabular} & mode-Ia & 5 & $\mathrm{E}$ \\
\hline DM17-0.75 & 1.24 & \multirow{3}{*}{112} & \multirow{3}{*}{1.67} & 1.05 & -1.23 & mode-Is & $\overline{5}$ & $\frac{L}{T}$ \\
\hline DM17-1.00 & 1.69 & & & 1.04 & -1.15 & mode-Ia & 5 & $\mathrm{E}$ \\
\hline DM17-1.25 & 2.10 & & & 1.04 & -1.14 & mode-II & 5 & $\mathrm{O}$ \\
\hline DM12-0.6 & 0.85 & \multirow{7}{*}{151} & \multirow{7}{*}{1.95} & 1.00 & -1.14 & mode-Is & 4 & $\mathrm{E}, \mathrm{T}$ \\
\hline DM12-0.7 & 1.00 & & & 1.02 & -1.15 & mode-Is & 4 & $\mathrm{E}$ \\
\hline DM12-0.8 & 1.14 & & & 1.03 & -1.14 & mode-Is & 5 & $\mathrm{E}$ \\
\hline DM12-0.9 & 1.29 & & & 1.07 & -1.13 & mode-Ia & 5 & $\mathrm{E}$ \\
\hline DM12-1.0 & 1.44 & & & 1.07 & \begin{tabular}{|l|}
-1.07 \\
\end{tabular} & mode-II & 5 & $\mathrm{E}$ \\
\hline DM12-1.1 & 1.58 & & & 1.05 & -1.05 & mode-II & 5 & $\mathrm{E}$ \\
\hline DM12-1.2 & 1.73 & & & 1.02 & \begin{tabular}{|l|}
-1.04 \\
\end{tabular} & mode-II & 5 & $\mathrm{E}$ \\
\hline DM10-0.7 & 0.90 & \multirow{7}{*}{181} & \multirow{7}{*}{2.18} & 0.95 & \begin{tabular}{|l|}
-1.02 \\
\end{tabular} & mode-Is & 4 & $\mathrm{E}$ \\
\hline DM10-0.8 & 1.03 & & & 0.94 & -1.00 & mode-Is & 5 & $\mathrm{E}$ \\
\hline DM10-0.9 & 1.17 & & & 1.00 & \begin{tabular}{|l|}
-1.04 \\
\end{tabular} & mode-Is & 5 & $\mathrm{E}$ \\
\hline DM10-1.0 & 1.30 & & & 1.03 & \begin{tabular}{|l|}
-1.03 \\
\end{tabular} & mode-Ia & 5 & $\mathrm{E}$ \\
\hline DM10-1.1 & 1.43 & & & 1.05 & \begin{tabular}{|l|}
-1.02 \\
\end{tabular} & mode-Ia & 5 & $\mathrm{E}$ \\
\hline DM10-1.2 & 1.56 & & & 0.98 & \begin{tabular}{|l|}
-0.94 \\
\end{tabular} & mode-II & 5 & $\mathrm{E}$ \\
\hline DM10-1.3 & 1.67 & & & 0.97 & \begin{tabular}{|l|}
-0.94 \\
\end{tabular} & mode-II & 5 & $\mathrm{E}$ \\
\hline DM8-0.8 & 0.93 & \multirow{10}{*}{216} & \multirow{10}{*}{2.46} & 0.88 & \begin{tabular}{|l|}
-0.89 \\
\end{tabular} & mode-Is & 4 & $\mathrm{E}$ \\
\hline DM8-0.9 & 1.05 & & & 0.92 & -0.92 & mode-Is & 5 & $\mathrm{E}$ \\
\hline DM8-1.0 & 1.17 & & & 0.94 & -0.92 & mode-Is & 5 & E \\
\hline DM8-1.1 & 1.29 & & & 0.96 & -0.93 & mode-Ia & 5 & $\mathrm{E}$ \\
\hline DM8-1.2 & 1.41 & & & 0.94 & -0.85 & mode-II & 5 & $\mathrm{E}$ \\
\hline DM8-1.4 & 1.65 & & & 0.86 & -0.83 & mode-II & 5 & $\mathrm{E}$ \\
\hline DM8-1.6 & 1.87 & & & 0.85 & -0.83 & mode-II & 6 & $\mathrm{E}$ \\
\hline DM8-1.8 & 2.11 & & & 0.85 & -0.81 & mode-II & 6 & $\mathrm{C}$ \\
\hline DM8-2.0 & 2.35 & & & 0.91 & -0.85 & mode-II & 6 & $\mathrm{C}$ \\
\hline DM8-2.2 & 2.59 & & & 0.84 & \begin{tabular}{|l|}
-0.78 \\
\end{tabular} & mode-II & 7 & $\mathrm{E}$ \\
\hline
\end{tabular}

注）八ッチ部は mode-II 形成後に断面が棈円状に大きく変形したものを表す。 亀裂位置の記号は以下の通り， $\mathrm{E}$ ：座屈波底部の端部側， $\mathrm{C}$ ：座屈波底部 の 2 波分の中間, $\mathrm{T} ：$ 座屈波頂部, $\mathrm{O}:$ 楕円状に変形後の多様な亀裂

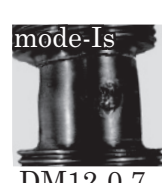

DM12-0.7

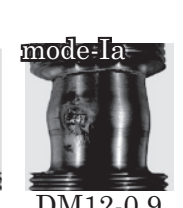

DM12-0.9
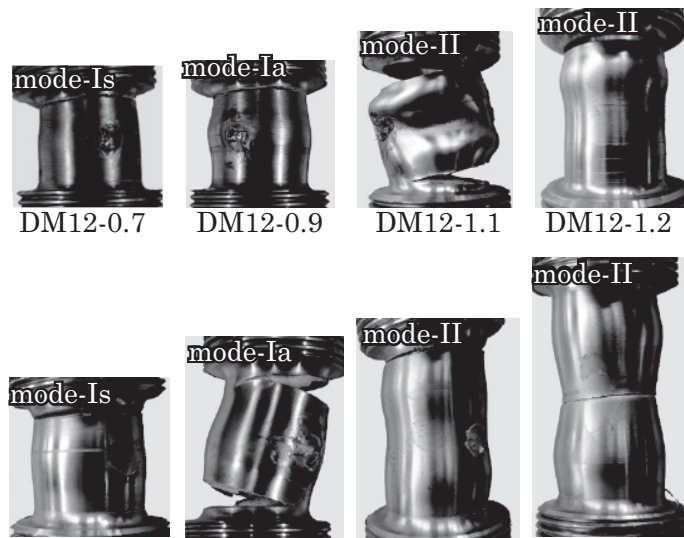

DM8-0.8
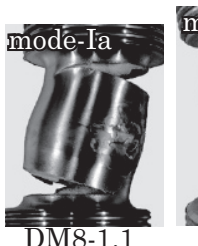

写真 1 軸方向載荷終了後の変形状況

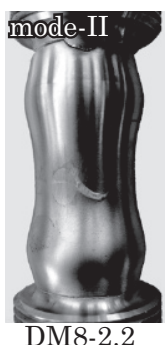

DM8-2.2
II と変化し, 各モードの境界は径厚比にかかわらず $L / l_{b}$ で概略区分 することができる。すなわち, mode-Is と mode-Ia の境界は $L / l_{b}$ が 1.2 程度, mode-Ia と mode-II の境界は $L / l_{b}$ が 1.4 程度となっている. 柱などで一般に使用される形状では，圧縮力作用時に材端 2 箇所で 局部座屈が発生するのに対し，本試験体は径長さ比が小さいという 特徵から 2 つ局部座屈波が干渉し, 長さによる局部座屈モードの 変化が見られる。

mode-II の場合，最大耐力までは 2 つ局部座屈波形が概ね対称 となっているのに対し, 耐力低下後は非対称に変形が進展する。 ま
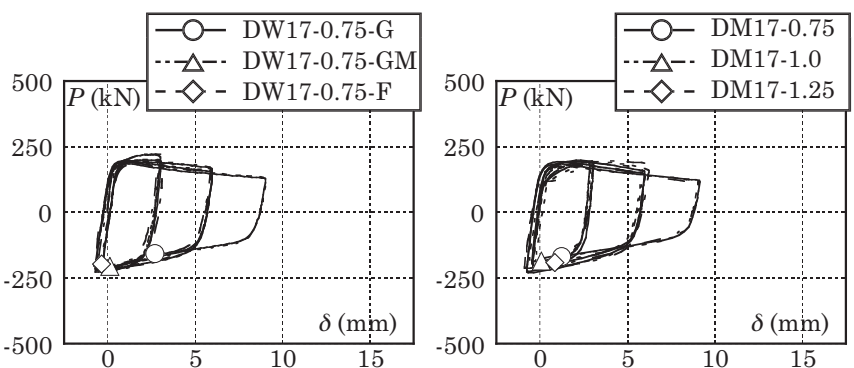

(a) DW シリーズ (溶接詳細の影響)

(b) DM シリーズ（径厚比 16.8）
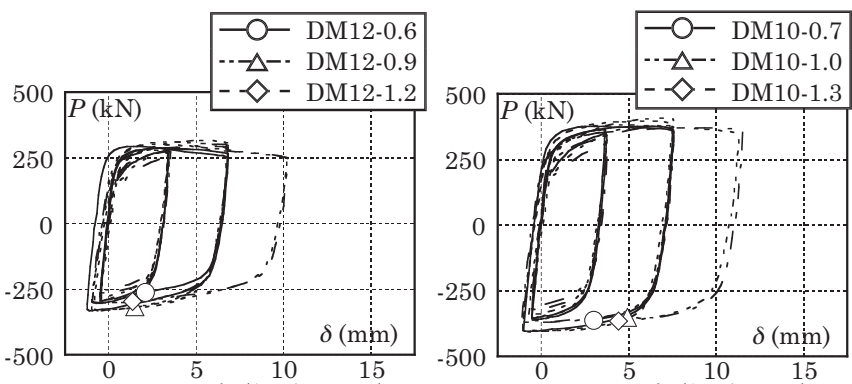

(c) DM シリーズ（径厚比 $12.2 ）$

(d) DM シリーズ（径厚比 9.9）
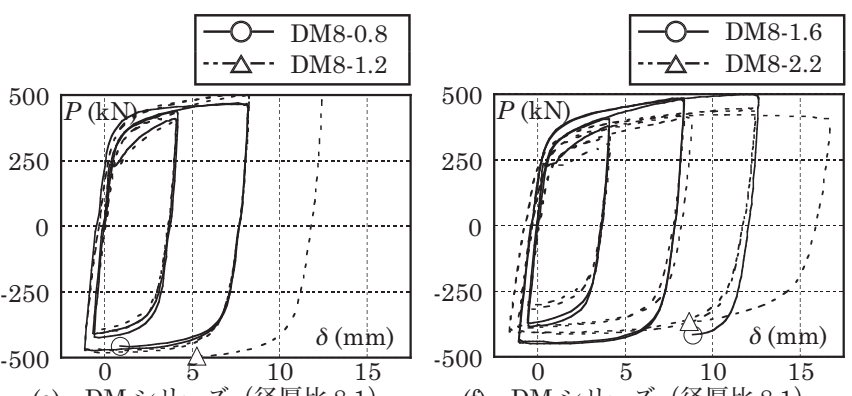

(e) DM シリーズ（径厚比 8.1）

図 6 軸力 $P$-軸変形量 $\delta$ 関係

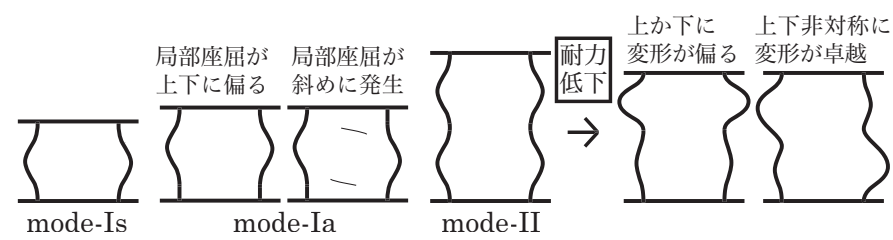

図 7 局部座屈モードの概要

た，径厚比が 12 程度以上の試験体の一部（DW17-1.25-G, DW171.50-G，DM17-1.25，DM12-1.1）では，2つの座屈波の間で内側に 窄む方向にも変形が進展し，断面が扁平な楕円状に変形した。鋼管 ダンパー内にアンカーボルトが挿入された実用の状況でこのような 変形が生じると，ねじ部に鋼管ダンパーが食い込むことが予想され る。この際，鋼管ダンパーとアンカーボルト間のクリアランスによ る影響を受けるものの，これを施工上，精度良く制御することが困 難である．また, 鋼管ダンパー交換を阻害する懸念もある，以上より， これら試験体（L/l $l_{b}$ が 1.4 程度以上かつ径厚比が 12 程度以上の形状） は実用化の対象から除外し, 以下の考察対象からも除外する.

(c) 亀裂発生状況および変形性能

急激な耐力低下を伴う大きな龟裂の発生は, 座屈波底部か座屈波 頂部で発生している（表 4 に示す通り，多くの試験体では前者）。 きな亀裂に至らなかった場合も，座屈波底部では外面に，座屈波頂 部では内面に, 多数の微細な亀裂が発生していた。これらの位置は, 圧縮力作用時の局部座屈により大きな圧縮歪が生じる箇所であり, 


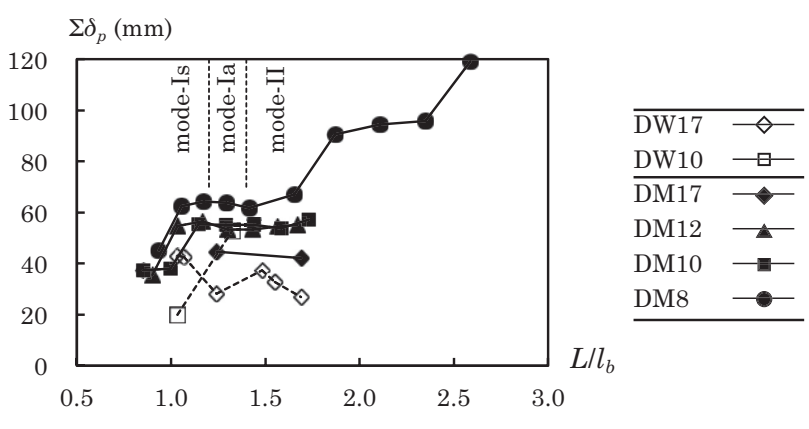

図 8 長さと累積塑性変形の関係

圧縮・引張の両方向の歪により亀裂が発生していることがわかる. なお，実用化対象外とした楕円状の局部座屈変形が生じる一部の試 験体においては，このような龟裂発生位置に加え，軸方向や斜め方 向にも亀裂が進展し，急激に耐力低下することなく亀裂が徐々に進 展するケースも見られた。

本項では，急激な耐力低下を伴う亀裂が発生するまでの累積塑性 変形 $\Sigma \delta_{p}$ を変形性能の指標として考察する。 $L / l_{b}$ と累積塑性変形 $\Sigma \delta_{p}$ の関係を図 8 に示す，機械加工型試験体では，ダンパー部において 亀裂が発生し，鋼管母材の伸び性能が発揮されたのに対し，鋼管溶 接試験体においては，いずれもダンパー部端部の溶接部において亀 裂が発生している，結果として，図 8 に示すように，鋼管溶接型試 験体（DWシリーズ）の変形性能は, 機械加工型試験体（DM シリー ズ）に比べて，半分程度からせいぜい同程度となっている。

以下では，機械加工型試験体を対象として，長さによる影響を考 察する. mode-Is を形成する場合, $L / l_{b}$ が 1.0 を下回ると, 短い試験 体ほど $\Sigma \delta_{p}$ が低くなる傾向がある。長さ $L$ が局部座屈波長計算值 $l_{b}$ よりも短い試験体では，ダンパー部両端の材端接合部からの拘束に より局部座屈波長が短くなり, 板要素の曲げ変形が大きくなること で，早期に亀裂が発生したものと考えられる。

mode-Ia を形成する場合， $L / l_{b}$ にかかわらず，亀裂発生時期が 5 サイクル目 $\left(l_{b}\right.$ の 0.3 倍の圧縮変形を経験した後の引張時 $)$ で, $\Sigma \delta_{p}$ が概ね一定となる，同じ mode-Ia で長さが異なる場合でも，局部座 屈が生じていない領域の軸方向変形が僅かになることから，P- $\delta$ 関 係や破断時期も同程度となったと考えられる。

径厚比が 8.1 (DM8 シリーズ) で mode-II を形成する場合, 破断 するまでほとんど耐力低下しないため，2つの局部座屈波の両方とも 変形し続けて塑性歪が分散され， $L / l_{b}$ が 1.9 以上の試験体になると破 断時期が 6 サイクル目以降に延びる。局部座屈波 2 つが変形する分, $\Sigma \delta_{p}$ も増え, L/l $l_{b}$ が 2.6 程度の試験体（DM8-2.2）では mode-Ia の 2 倍程度の $\Sigma \delta_{p}$ が得られるが，より短い試験体の $\Sigma \delta_{p}$ はそれよりも小 さくなる。これは，L/l $L$ が 2 以下の場合は局部座屈 1 つ分で見れば, 局部座屈波長が短くなっていることや，中央の局部座屈の谷間で歪 が集中したことに起因していると考えられる.

径厚比が 10 程度以上（DM17，DM12，DM10 シリーズ）で mode-II を形成する場合は，既述の通り，アンカーボルトと接触する ような内側に窄む楕円状の変形が生じ得ることもあり，望ましい変 形性状ではない. また, 楕円状にならずに局部座屈が 2 つ発生しても, 比較的早い段階で耐力低下する。 その結果，局部座屈のどちらか一 方に変形が集中するか，非対称な変形が生じ，歪が集中する箇所が できるので, 長くても変形性能が向上しないものと考えられる.

\section{4 ダンパーの設計条件}

本鋼管ダンパーを設計するに際して, 変形性能を確保することが 肝要となる。このため, 鋼管溶接型は不適と判断し, 機械加工型の みを採用する。この他の設計条件を設定するにあたっては，以下の 通り, 長くて変形性能が高い高性能夕イプと短くて変形性能がやや 低い標準タイプの2 種類の仕様が考えられる.

○高性能タイプの設計条件 :

・径厚比を 8 程度とする.

・長さを局部座屈波長計算值の 2.6 倍程度とする.

○標準タイプの設計条件 :

・径厚比を $8 \sim 12$ 程度とする.

・長さを局部座屈波長計算值の $1.2 \sim 1.4$ 倍程度の範囲とする. 急激な耐力低下を伴う大きな亀裂の発生までに，径厚比が 17 程度 の試験体では局部座屈により降伏耐力 ${ }_{c} P_{y}$ を下回るほど大きく耐力低 下したのに対し, 径厚比 12 程度以下であれば局部座屈による耐力低 下が ${ }_{c} P_{y}$ の 1.5 倍程度（最大耐力の 8 割程度）までにとどまることか ら，径厚比の設定を設けている，長さについては，標準夕イプでは， mode-Ia が形成されるかそれと同等の変形性能を確保できることを 意図している，高性能夕イプは，最も変形性能が良かった DM8-2.2 と同様の形状となることを意図している.

\section{3. 鋼管ダンパーを適用した露出柱脚の載荷実験}

\section{1 実験計画}

鋼管ダンパーを露出柱脚に適用した場合，鋼管ダンパーには，軸 力だけではなく，曲げモーメントやせん断力も作用する。この影響 を確認するとともに，ダンパー以外の露出柱脚各部の挙動を確認す るために，鋼管ダンパーを適用した露出柱脚の載荷実験を行う。

ダンパー部の形状は，標準タイプ（DM12-0.9 と DM8-1.0 に相当） と高性能タイプ（DM8-2.2 に相当）を採用する。試験体は，図 9 に 示すように, 1 つの箱形断面柱に 4 つの鋼管ダンパーが組み込まれた ものとする，基礎には簡易に実験するため鉄骨基礎梁を用い，その 上に設置する耐圧板とベースプレートの間にはグラウトモルタルを 打設している，耐圧板のボルト孔にはアンカーボルトとの隙間にも グラウトを充填することで，アンカーボルトの曲げを拘束している. 柱・アンカーボルト・基礎梁については, 最大耐力時にも弾性とな るよう設計している。 また，ベースプレートの直下にはシアキーを 設置している，ただし，シアキーの仕様は，鉄骨基礎梁を利用して いるため，想定される実仕様（RC 造基礎梁の中まで埋め込まれる仕 様）とは異なる (図 9(b) 参照)。アンカーボルトは，グラウトモル夕 ル養生中は仮締めとして, 載荷直前にナット・ロックナットとも本 締め（180 Nm 程度）しており，1本あたり $30 \sim 50 \mathrm{kN}$ 程度の初期 張力が導入されている.

試験体一覧を表 5 に示す. 試験体のパラメータは, ダンパーの形状, シアキーの有無，柱軸力の有無とする．実験ごとに，ダンパーとグ ラウトを（塑性化が確認された場合はアンカーボルトも）交換する. 柱軸力は使用するダンパー 1 本の降伏耐力計算值 ${ }_{c} P_{y}$ の 4 倍（柱軸 力比に換算すると 0.1 程度) の圧縮軸力を導入する.

本実験で用いる鋼管ダンパーは，前章の要素実験 DM シリーズと 同様 $\phi 76.3 \times 25$ の鋼管（STKM13A）から機械切削により製作してい る(図 10)。グラウトモルタルは，プレミックスタイプを使用して 


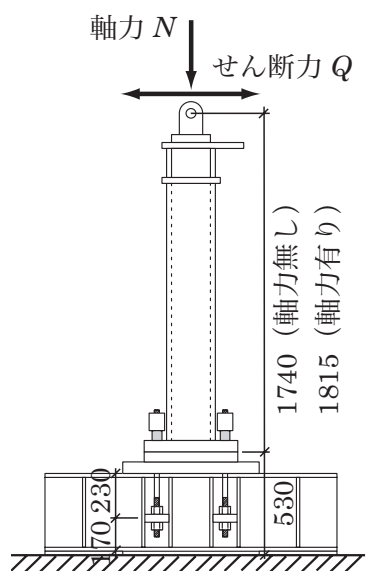

(a) 全体

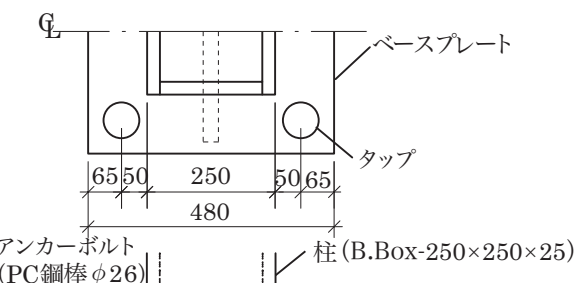

$(\mathrm{PC}$ 鋼棒 $\phi 26)$ 献
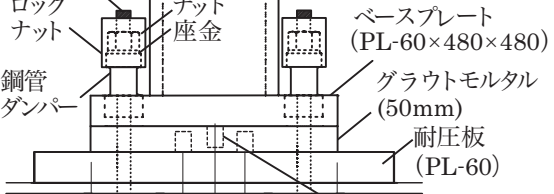

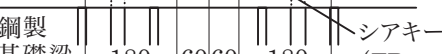

基礎梁, 180 60 60,180 (FB-30×40×440)

(b) 柱脚部

図 9 試験体の概要
(単位 $: \mathrm{mm}$ ) (単位：mm)

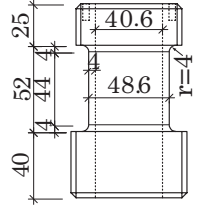

(a)DM12-0.9

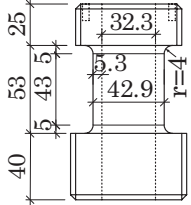

(b)DM8-1.0

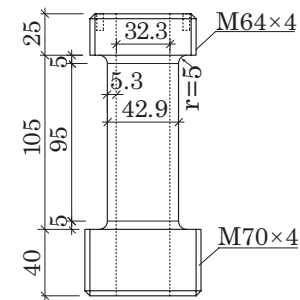

(c)DM8-2.2
図 10 ダンパーの形状

いる．ただし， $\mathrm{RC}$ 造基礎梁を用いた際にベースプレートからの圧縮 応力によって生じると想定されるコンクリートの変形を模擬するた めに，グラウトモルタルは基礎コンクリートと同程度の圧縮強度（目 標強度が $24 \mathrm{~N} / \mathrm{mm}^{2}$ ) となるよう水量・材歯を調整している。使用材 料の試験結果を表 6 に示す。なお，試験体 BM8-2.2-K-0.1 では，グ ラウトモルタルとベースプレート下面の間に充填不良が認められた。

載荷方法は，図 9(a) に示すように，柱に一定の圧縮軸力 $N$ を与え つつ柱頭部に正負交番繰り返しせん断力 $Q$ をオイルジャッキにより 作用させるものとする，載荷履歴は，まず，柱脚曲げモーメント $M_{b}$ がダンパー降伏時の柱脚曲げモーメント計算值 ${ }_{c} M_{y}$ (算出方法は後述) の 0.75 倍を目標とする荷重制御のサイクルを 2 サイクル経た後, 柱 脚回転角 $\theta_{b}$ により変位制御し, $\pm(0.005,0.015,0.025,0.035,0.045$, $0.055 ， 0.065 ） \mathrm{rad}$ をそれぞれ 2 サイクルずつ与える正負交番繰り 返し載荷とする，柱脚回転角 $\theta_{b}$ は基礎梁上面とベースプレートの相 対回転角であり, 2 点の鉛直変位から換算している。この載荷履歴は, 軸力ありの試験体の鋼管ダンパーが要素実験と同程度の載荷履歴と なることを意図している。

\section{2 実験結果}

(a) 曲げモーメントー柱脚回転角関係および破壊性状

図 11 に実験から得られた $M_{b}-\theta_{b}$ 関係を示す。ただし，図中の 印はダンパーに亀裂が入った時点を， \印はダンパーが完全に破断 した時点を示す。また，4つあるダンパーのうちのいずれかに初めて 亀裂が生じる時点より前を太線で，それより後を細線で表す。柱脚 の曲げ抵抗要素としては，曲げ圧縮側鋼管ダンパーに作用する引張 応力と曲げ引張側鋼管ダンパーに作用する圧縮応力（アンカーボル トと鋼管ダンパーには逆方向の軸力が作用する）およびベースプレー トーグラウトモルタル間の材間圧縮力（以下，単にグラウト圧縮応力 と称す）がある。これらによる応力伝達機構が軸力の大きさによっ
表 5 試験体一覧

\begin{tabular}{|l|l|c|c|}
\hline \multicolumn{1}{|c|}{ 試験体名 } & ダンパー形状 & シアキー & 軸力 $(\mathrm{kN})$ \\
\hline \hline BM12-0.9-N & DM12-0.9 & なし & 0 \\
\hline BM12-0.9-K & DM12-0.9 & あり & 0 \\
\hline BM12-0.9-K-0.1 & DM12-0.9 & あり & 640 \\
\hline BM8-1.0-K & DM8-1.0 & あり & 0 \\
\hline BM8-2.2-K & DM8-2.2 & あり & 0 \\
\hline BM8-2.2-K-0.1 & DM8-2.2 & あり & 716 \\
\hline
\end{tabular}

表 6 材料試験結果

(a) 鋼管ダンパー

\begin{tabular}{|c|c|c|c|}
\hline & $\begin{array}{c}\text { 降伏強さ } \\
\left(\mathrm{N} / \mathrm{mm}^{2}\right)\end{array}$ & $\begin{array}{l}\text { 引張強さ } \\
\left(\mathrm{N} / \mathrm{mm}^{2}\right)\end{array}$ & $\begin{array}{l}\text { 伸び* } \\
(\%)\end{array}$ \\
\hline \hline 試験結果 & 286 & 453 & 45 \\
\hline \hline JIS規格值 & 215 以上 & 370 以上 & 30 以上 \\
\hline
\end{tabular}

* : 4 号試験片による

(b) グラウトモルタル

\begin{tabular}{|l|c|c|c|}
\hline \multicolumn{1}{|c|}{ 試験体名 } & $\begin{array}{c}\text { 圧縮強度 } \\
\sigma_{c}\left(\mathrm{~N} / \mathrm{mm}^{2}\right)\end{array}$ & $\begin{array}{c}\text { 圧縮強度時歪 } \\
\varepsilon_{\mathrm{co}}(\%)\end{array}$ & $\begin{array}{c}\text { ヤング係数 } \\
E_{c}\left(\mathrm{kN} / \mathrm{mm}^{2}\right)\end{array}$ \\
\hline \hline BM12-0.9-N & 22.3 & 0.22 & 18.4 \\
\hline BM12-0.9-K & 23.4 & 0.33 & 15.7 \\
\hline BM12-0.9-K-0.1 & 26.9 & 0.48 & 20.0 \\
\hline BM8-1.0-K & 33.5 & 0.41 & 17.7 \\
\hline BM8-2.2-K & 30.4 & 0.30 & 21.4 \\
\hline BM8-2.2-K-0.1 & 18.7 & 0.42 & 12.4 \\
\hline
\end{tabular}

て異なり，履歴曲線も異なる傾向を示す，以下では，図 12 に示す概 要図を用いて，その挙動と応力伝達機構の変遷を解説する。

軸力なしの試験体においては，図 11(a)，(b)，(d)，(e)からわかる ように，ダンパーに亀裂が入るまでは紡錘形の履歴挙動を示す。ア ンカーボルトに小さな初期張力が導入されているため, ベースプレー トが離間するまでの低い応力レベルまでは高い剛性を示す。離間後, 曲げ圧縮側鋼管ダンパーに生じる応力は小さい状態のまま，曲げ引 張側ダンパーが降伏して曲げ耐力は概ね一定となる（図 12(a) 中の $\mathrm{o} \rightarrow \mathrm{a}$ 区間)．曲げ引張側鋼管ダンパーが圧縮降伏した後，曲げ応力 が反転すると，接触していたベースプレートとグラウトモルタルが 離間して, 曲げ引張側と曲げ圧縮側の鋼管ダンパーのみが曲げ応力 に抵抗し，概放同時に両者の塑性変形が生じる（図 12(a) 中の b $\rightarrow c$ 区間)。その後，曲げ圧縮側でベースプレートとグラウトモルタルが 接触すると, 曲げ圧縮側の鋼管ダンパーの塑性変形はとどまり, 曲 げ引張側の鋼管ダンパーの塑性変形が進展することで柱脚回転角が 増大する (図 12(a) 中の $\mathrm{c} \rightarrow \mathrm{d}$ 区間).

軸力ありの試験体においては, 図 11(c), (f) からわかるように, 夕゙ ンパーに亀裂が入るまではくびれた紡錘形の履歴挙動を示す。軸力 およびアンカーボルト初期張力による回転抵抗のため, 高剛性で曲 げモーメントが増加した後, 曲げ圧縮側鋼管ダンパーに生じる応力 は小さいまま，曲げ引張側鋼管ダンパーとグラウトモルタルの圧縮 応力により曲げ抵抗する（図 12(b) 中の o $\rightarrow$ a 区間）。曲げ引張側鋼 管ダンパーが圧縮降伏した後，曲げ応力が反転すると，柱圧縮軸力 により曲げ圧縮側鋼管ダンパーの負担が大きいために，同部が先行 して降伏する (図 $12(\mathrm{~b})$ 中の $\mathrm{b} \rightarrow \mathrm{c}$ 区間)。その後， $\theta_{b}=0$ 付近にお いて曲げ圧縮側のベースプレート先端でグラウトモルタルと接触す ると, 同部での曲げ抵抗への寄与度が大きいために耐力は再上昇し, 曲げ引張側鋼管ダンパーが降伏すると再び曲げ耐力は概补一定とな る（図 12(b) 中の $\mathrm{c} \rightarrow \mathrm{d}$ 区間)．曲げ耐力が一旦横ばいとなり，履歴 曲線がくびれるのは，以上の挙動を示すためである。なお，試験体 BM8-2.2-K-0.1 においては, 軸力導入時にアンカーボルト初期張力 


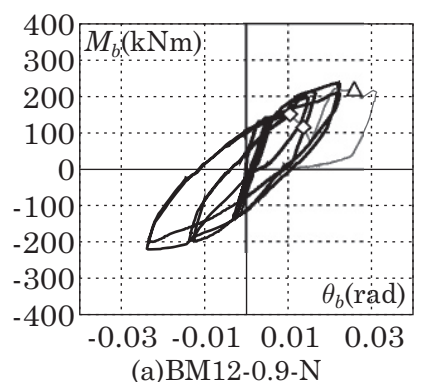

(a)BM12-0.9-N

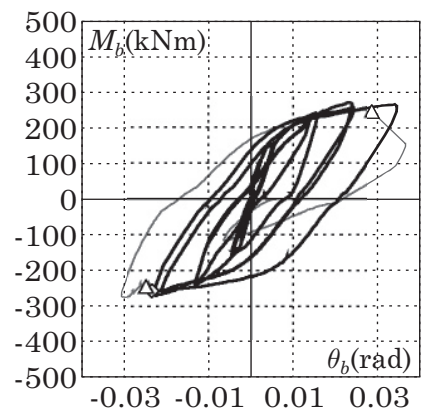

(d)BM8-1.0-K

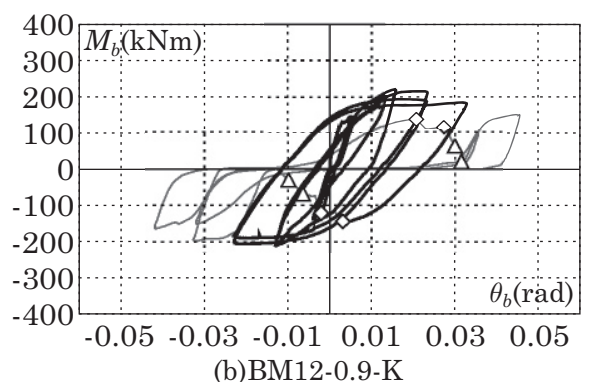

(b)BM12-0.9-K

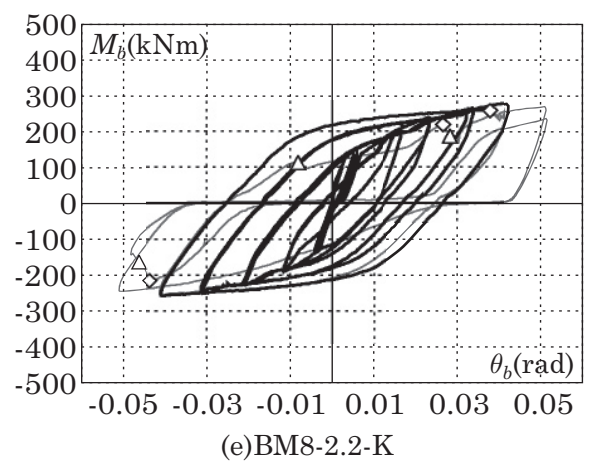

図 $11 M_{b}-\theta_{b}$ 関係

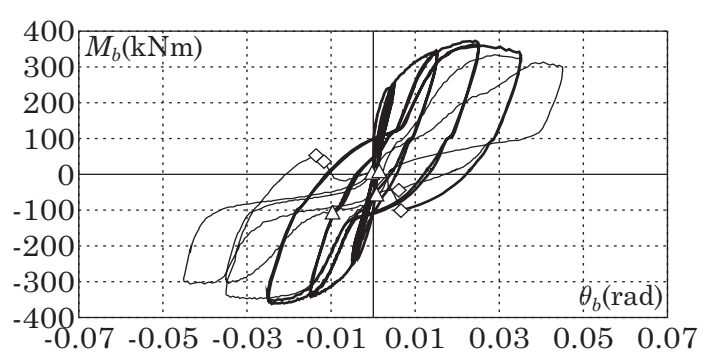

(c)BM12-0.9-K-0.1

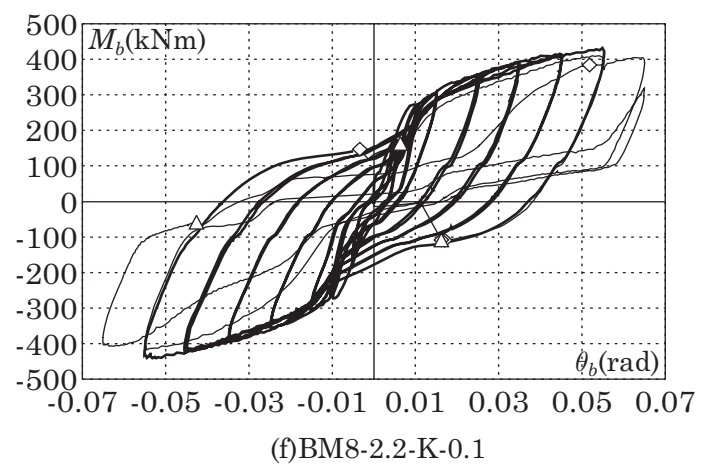

a

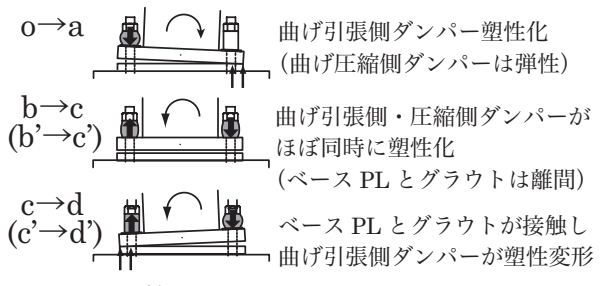

(a) 軸力な U

図 12 亀裂発生前の履歴曲線と応力伝達機構の概要

が消失し, 水平力作用時当初ごく僅かなスリップ性状を示した.こ れは, グラウトモルタルの充填不良によるものと考えられる。

亀裂発生までの変形性能については, シアキーありの標準タイプ では $\theta_{b}$ が $\pm 0.035 \mathrm{rad}$ のサイクルで亀裂が発生したのに対して, 高性 能タイプでは $\theta_{b}$ が $\pm 0.045 \mathrm{rad} \sim \pm 0.055 \mathrm{rad}$ のサイクル゙亀裂が発 生し, 標準タイプより高い変形性能が確認された。今回の軸力の範 囲では，鋼管ダンパーのいずれかに亀裂が発生すると，曲げ耐力が 一時的に低下するものの, すぐに再上昇し, 概䄈亀裂発生前の耐力 にまで回復する。これは, 曲げ圧縮側鋼管ダンパーに亀裂が発生し た後も, その応力をグラウト圧縮応力で負担することができ, 他方, 曲げ引張側鋼管ダンパーでは亀裂発生後も再接触することでそれ以 前と同様に圧縮応力を伝達できるためである. 全ての鋼管ダンパー で破断するとアンカーボルト先行降伏型の露出柱脚と同様の応力伝 達機構となるため, 軸力なしの場合にスリップ型, 軸力ありの場合 にフラッグ型の履歴挙動に順次移行する.

\section{(b) 水平方向の挙動}

鋼管ダンパーを適用した露出柱脚では, 上述の通り, 軸力の大き さ次第で, 曲げ圧縮側でベースプレートーグラウトモルタル間が離間 した状態で曲げ抵抗する状況になり得る。その間, せん断力に対し てベースプレートーグラウトモルタル間の摩擦力により抵抗できず, 鋼管ダンパーおよびアンカーボルトが負担するせん断力が大きくな る。このようなせん断抵抗機構がシアキーの有無や軸力によって変 化するため, 図 13 に示すように, 試験体ごとの柱脚の水平変位量

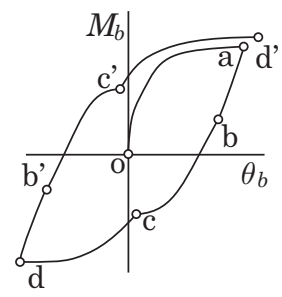

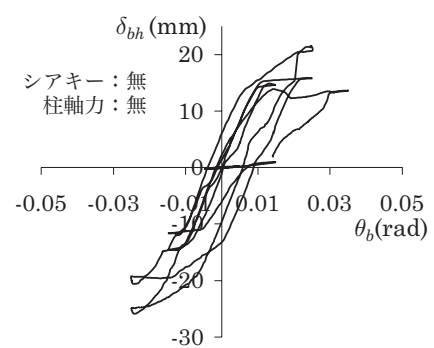

(a) $\quad$ BM12-0.9-N

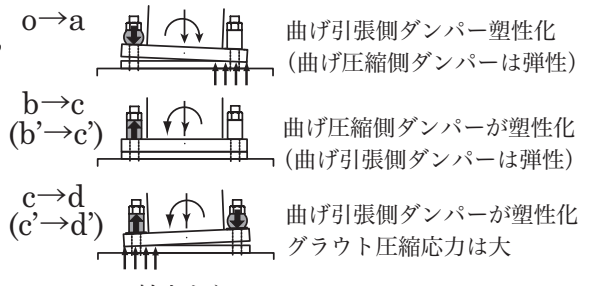

(b) 軸力あり
図 13 柱脚の水平変位量の推移

$\delta_{b h}$ に大きな差が生じる.

シアキーがない BM12-0.9-Nではベースプレート離間時に他の 試験体と比べて大きく水平移動した（最大で $26 \mathrm{~mm}$ )。これに対し, BM12-0.9-K はシアキーを取り付けたため, 柱脚回転角が大きくなっ ても, 柱脚全体での水平移動量は BM12-0.9-N に比べて数割程度（最 大で $7 \mathrm{~mm}$ )にとどまった. なお, 鋼管ダンパーに亀裂が発生するまで, BM12-0.9-N と BM12-0.9-K は, 概㸚同様の $M_{b}-\theta_{b}$ 関係を示している. シアキーを有する同じ試験体形状であっても, 軸力がゼロの場合, 圧縮軸力導入時よりも水平変位量が大きい。すなわち, 本試験体の シアキーでは, せん断抵抗要素として十分な耐力を有しておらず, 圧縮軸力導入によって得られる摩擦力が加算されることによって, 水平変位を抑えら机たと言える（BM12-0.9-K-0.1 で最大 $3 \mathrm{~mm}$ 程度, BM8-2.2-K-0.1 で最大 $4 \mathrm{~mm}$ 程度)。軸力ゼロの試験体ではシアキー 
周辺のグラウトモルタルの損傷が比較的大きい

水平変位が生じると, アンカーボルトに曲げせん断応力が作用す る. 歪が最大になると考えられる基礎梁上端位置において計測され た測定值によると，シアキーを有する試験体では，鋼管ダンパーの 亀裂進展前にアンカーボルトは塑性化していない。これに対し，シ アキーがない試験体（BM12-0.9-N）では亀裂発生前にアンカーボル トが塑性化し，シアキーがあっても軸力がない試験体（BM8-2.2-K） では鋼管ダンパーの亀裂後にアンカーボルトが塑性化している。こ れは, 亀裂が発生することで伝達されていたせん断力が亀裂が発生 していない鋼管ダンパーおよびアンカーボルトに移ったためと考え られる. 水平変位による鋼管ダンパーへの影響は次項で考察する.

(c) 鋼管ダンパーの挙動

柱脚に組み込まれた鋼管ダンパーでは，要素実験とやや異なる性 状を示す．正載荷時曲げ引張側となる鋼管ダンパーの軸力 $P-$ 軸変形 $\delta$ 関係と実験終了後の状況を図 14 , 鋼管ダンパー軸力の最大耐力お よび変形性能を表 7 にそれぞれ示す，Pの測定にはアンカーボルト 軸部（定着板から $150 \mathrm{~mm}$ 上の位置）に貼付した 2 枚の歪ゲージを 用いており，予め実施した校正結果に基づいて軸力に換算している. 鋼管ダンパーの軸変形量 $\delta$ はロックナットとベースプレートの相対 変位として計測している.

ダンパー部分の載荷履歴を見ると, 軸力がある場合, 曲げ圧縮側 で鋼管ダンパーの $\delta$ が負方向載荷でゼロに近いところまで戻ってい
る（要素実験と大略同じ）のに対し，軸力がない場合，中立軸位置 が圧縮縁に近いために，曲げ圧縮側鋼管ダンパーでも $\delta$ がゼロに戻 りにくく, 徐々に正方向の残留変形が増加している.

鋼管ダンパーの変形状態を観察すると, 要素実験の結果と同様, 標準タイプの試験体では局部座屈波 1 波分の局部座屈（mode-Ia）が 生じ, 高性能夕イプの試験体では 2 波分の局部座屈（mode-II）が生 じている．これに加えて，鋼管ダンパーには，ベースプレートの傾 斜や水平変位に伴い，曲げせん断変形が生じる。軸力ありの試験体 の方が軸力なしの試験体よりも亀裂発生（図 14 中の〉）までの変形 性能が高かったのは，この曲げせん断変形が小さかったためと考え られる。

鋼管ダンパー単体として評価した場合に，以上のような載荷履歴 の違いや曲げせん断変形の影響を検証するために, 要素実験の結果 と比較する。表 7 に示すように, 最大圧縮耐力を ${ }_{e} P_{\max } /{ }_{c} P_{\text {max }}$ によ り要素実験と比べると, 標準夕イプでは 1 割ほど低下し, 高性能夕 イプでは同程度となっている。これは，同程度の水平変位が生じた 場合に，短い標準夕イプの方が鋼管ダンパーに生じる変形角が大き くなることが影響していると考えられる. 結果的に, 両タイプとも ${ }_{e} P_{\max } /{ }_{c} P_{\max }$ の值は 0.9 程度となっている.

鋼管ダンパー単体の変形性能については, とりわけ, シアキーな しの BM12-0.9-N で累積塑性変形 $\Sigma \delta_{p}$ が要素実験の半分以下に, 他 の標準タイプについても, 半分程度に低下していることがわかる.

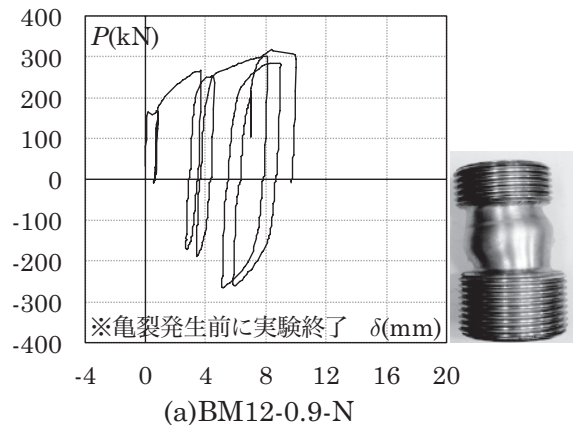

(a)BM12-0.9-N

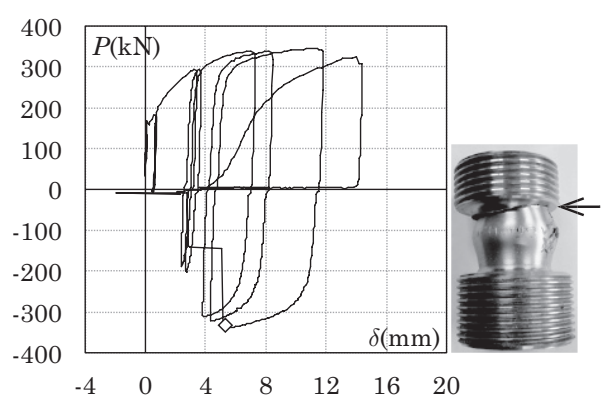

(d)BM8-1.0-K

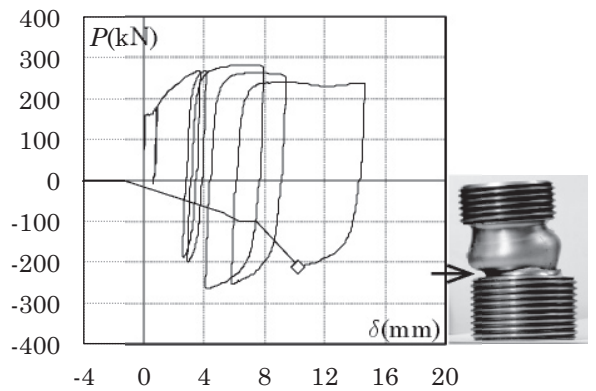

(b)BM12-0.9-K

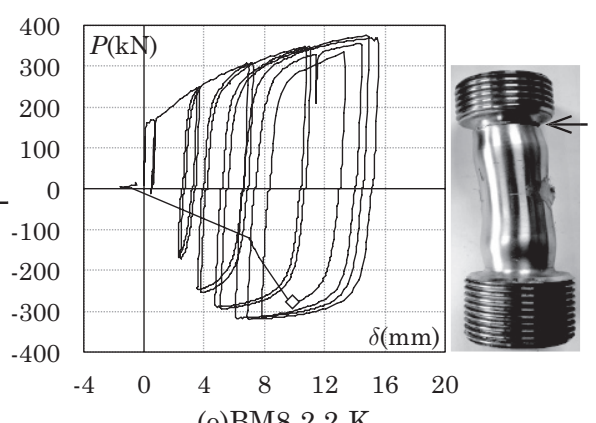

(e)BM8-2.2-K

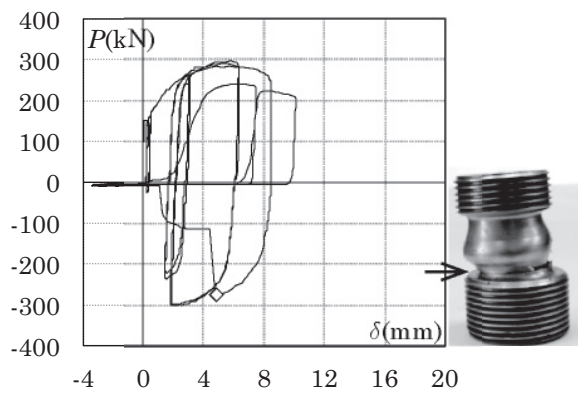

(c)BM12-0.9-K-0.1

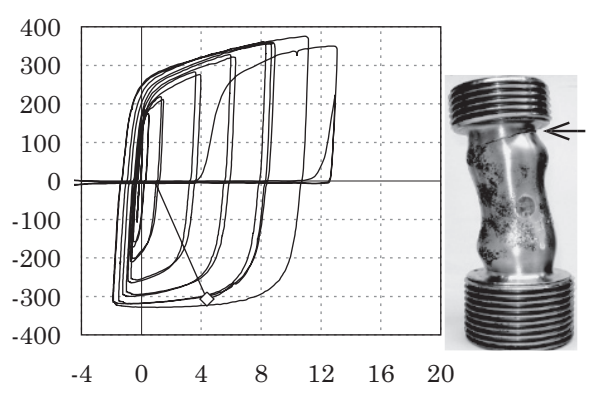

(f)BM8-2.2-K-0.1

図 14 鋼管ダンパーの軸力 $P-$ 軸変形量 $\delta$ 関係

$\diamond:$ 亀裂発生 (グラフ $\leftarrow$ : 亀裂位置 (写真)

表 7 鋼管ダンパーの実験結果一覧

\begin{tabular}{|c|c|c|c|c|c|c|c|c|c|c|c|c|c|}
\hline \multirow[b]{2}{*}{ 試験体名 } & \multirow[b]{2}{*}{$\frac{{ }_{c} P_{\max }}{{ }_{c} P_{y}}$} & \multicolumn{6}{|c|}{${ }_{e} P_{\max } /{ }_{c} P_{\max }$} & \multicolumn{6}{|c|}{$\Sigma \delta_{p}(\mathrm{~mm})$} \\
\hline & & $\begin{array}{l}\text { 正載荷 } \\
\text { 曲げ弓 }\end{array}$ & & \begin{tabular}{|l} 
正載荷 \\
曲げ压
\end{tabular} & & 平均 & $\begin{array}{l}\text { 要素* } \\
\text { 実験 }\end{array}$ & $\begin{array}{l}\text { 正載荷 } \\
\text { 曲げ引 }\end{array}$ & & \begin{tabular}{|l} 
正載荷 \\
曲げ压
\end{tabular} & & 平均 & $\begin{array}{l}\text { 要素* } \\
\text { 実験 }\end{array}$ \\
\hline BM12-0.9-N & \multirow{3}{*}{1.89} & 0.99 & 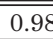 & 1.05 & 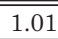 & 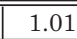 & \multirow{3}{*}{1.07} & - & - & 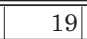 & 20 & 19.6 & \multirow{3}{*}{55} \\
\hline BM12-0.9-K & & 0.93 & 0.92 & 0.93 & 0.91 & 0.92 & & 30 & 30 & 33 & 25 & 29.4 & \\
\hline BM12-0.9-K-0.1 & & 0.97 & 0.93 & 0.98 & 0.95 & 0.96 & & 48 & 29 & 32 & 35 & 35.9 & \\
\hline BM08-1.0-K & \multirow{3}{*}{2.37} & 0.88 & 0.87 & 0.81 & 0.88 & 0.86 & 0.94 & 34 & - & 31 & - & 32.6 & 64 \\
\hline BM08-2.2-K & & 0.87 & 0.89 & 0.88 & 0.89 & 0.89 & \multirow{2}{*}{0.84} & 65 & - & 93 & 74 & 77.2 & \multirow{2}{*}{119} \\
\hline BM08-2.2-K-0.1 & & 0.88 & 0.90 & 0.89 & 0.89 & 0.89 & & 122 & 128 & 124 & 106 & 120 & \\
\hline
\end{tabular}

: 亀裂発生前に実験終了 したために值が得られな かったものを表す. : ダンパー部が同形状の 要素実験試験体の実験 值を比較対象として示し ている. 
また, 高性能夕イプでは, 変形性能の低下は比較的小さい. ただし, 載荷履歴の違いなども影響しているため, 鋼管ダンパーの累積塑性 変形 $\Sigma \delta_{p}$ のみで一概に変形性能を評価することは難しい．また， RC 造基礎梁を用いた際に想定される実仕様においても, 同等以上のせ ん断耐力をシアキーに付与することは可能と推察されるものの，実 験的な検証はできておらず，変形性能の定量的な評価については， 今後の検討課題である.

\section{4. 鋼管ダンパーを適用した露出柱脚の構造性能}

\section{1 弾性剛性の評価}

前章の実験結果に示したように，鋼管ダンパーが塑性化する以前 は，曲げ圧縮側鋼管ダンパーの応力は小さい。このことから，本工 法を適用した露出柱脚の弾性岡性 ${ }_{c} K_{b}$ についても，一般的な露出柱 脚の弾性剛性の評価式 8) を援用し次式により評価する。

$$
{ }_{c} K_{b}=\frac{E \cdot n_{t} \cdot a_{a}\left(d_{t}+d_{c}\right)^{2}}{R \cdot l_{e}}
$$

ここに, $n_{t}$ : 曲げ引張側アンカーボルト本数, $a_{a}$ : アンカーボルト軸 部断面積, $d_{t}$ : 曲げ引張側アンカーボルト断面群と柱断面図心との距 離, $d_{c}$ : 曲げ圧縮側柱断面最外縁と柱断面図心との距離, $l_{e}$ : アンカー ボルト有効長さ $\left(=l_{a}+L a_{a} / a_{d}, l_{a}\right.$ :アンカーボルトのナット間長さ, $L$ : ダンパー部の長さ, $a_{d}$ : 鋼管ダンパーの断面積), $R:$ アンカーボル ト以外の変形による剛性低減係数. 本システムにおいては, アンカー ボルトの伸びだけではなく，曲げ引張側鋼管ダンパーの縮み量も付 加されるので，(3) 式の $l_{e}$ はこの点を考慮している，また，本実験に おいては，ベースプレートが一般的な板厚よりも厚いことや，鉄骨 基礎梁の定着部では抜け出しがほとんど生じないことを考慮して, $R$ = 1 とする.

\section{2 曲げ耐力の評価}

弾性限を表すための降伏耐力，柱脚としての終曲耐力を表すため の全塑性耐力，柱など柱脚以外の設計をするための最大耐力の 3 段
階の耐力を設定する。耐力式には，一般化累加強度式を用いる。図 15 に示すように，耐力算出のために想定する応力分布は，鋼管夕夕 ンパーを引張・圧縮の両方向に抵抗する集中力とし, ベースプレー ト下面の圧縮応力は，矩形ストレスブロックとする．３段階の耐力 算定時に，鋼管ダンパーの軸耐力 $P_{u}$ とコンクリート圧縮耐力 $C_{u}$ に 異なる大きさを設定することで，同じ相関曲線式により，降伏耐力 ${ }_{c} N_{y} \cdot{ }_{c} M_{y}$, 全塑性耐力 ${ }_{c} N_{p} \cdot{ }_{c} M_{p}$, 最大耐力 ${ }_{c} N_{\max } \cdot{ }_{c} M_{\max }$ を算定す ることができる.

以上の条件により得られる軸力と曲げの相関曲線式を表 8 に示す. 表中の $N$ および $M$ は，各段階の耐力を表している。 ベースプレート 下面のストレスブロックの強度 $f_{c}$ を, 降伏曲げ耐力算出時には短期 許容応力度 (圧縮強度 $F_{c}$ の $2 / 3$ 倍), 全塑性曲げ耐力時には $0.85 F_{c}$, 最大曲げ耐力算定時には $F_{c}$ としている，本実験では， $\mathrm{RC}$ 造基礎梁 上面のコンクリート圧縮耐力の代わりに，グラウトモルタルの圧縮 耐力を用いる．鋼管ダンパーの軸耐力は，降伏曲げ耐力算出時には 降伏耐力 ${ }_{c} P_{y}$, 最大曲げ耐力算定時には前章の考察に基づき，最大圧 縮耐力計算值 ${ }_{C} P_{\text {max }}$ の 0.9 倍としている. 全塑性曲げ耐力算出時には, 鋼管ダンパーが降伏してから最大耐力に達するまでの平均的な軸耐 力を表すことを意図して, 降伏耐力と最大耐力の平均として扱う.

\section{3 構造性能の評価結果}

弾性剛性の実験值 ${ }_{e} K_{b}$ については，ベースプレートが離間するま での高剛性域を除き, 軸力 $N$ やアンカーボルト初期張力 $P_{o}$ による 抵抗モーメント $M_{n}\left(=N d_{c}+P_{o}\left(d_{c}+d_{t}\right)\right)$ 時から降伏曲げ耐力 ${ }_{e} M_{y}$ （鋼管ダンパー降伏時）までの概ね線形域となる範囲を評価する ${ }^{9}$. $P_{o}$ については, 柱軸力導入時点での実験值を用いる. なお, BM82.2-K-0.1 についてはナット締結時に導入された初期張力が軸力導入 後にほぼ䘫失していた。これは，グラウトモルタルの充填不良の影 響により，グラウトモルタルに圧縮変形が生じたためと考えられる. 弾性剛性の計算值と実験值の比較を表 9 に示す。軸力が作用した場 合に実験值が計算值よりもやや高くなる傾向にあるものの，(3) 式と

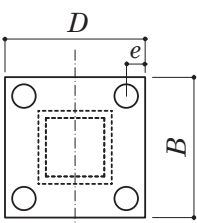

(1)

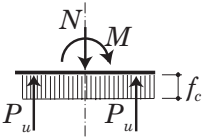

(2)

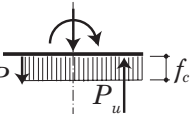

(3)

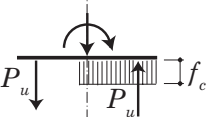

(4)

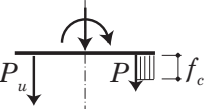

(5)

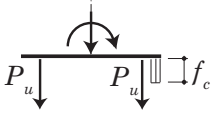

図 15 曲げ耐力 計算時の応力状態
表 8 各応力状態における $N-M$ 相関曲線式

\begin{tabular}{|l|l|l|}
\hline 状態 & \multicolumn{1}{|c|}{$N$ の範囲 } & \multicolumn{1}{|c|}{ 相関曲線式 } \\
\hline$(1)$ & $C_{u}\left(1-\frac{e}{D}\right)+2 P_{u} \leq N \leq C_{u}+2 P_{u}$ & $M=\frac{D}{2}\left(N-2 P_{u}\right)\left(1-\frac{N-2 P_{u}}{C_{u}}\right)$ \\
\hline$(2)$ & $C_{u}\left(1-\frac{e}{D}\right) \leq N<C_{u}\left(1-\frac{e}{D}\right)+2 P_{u}$ & $M=-\left(N-2 P_{u}\right)\left(\frac{D}{2}-e\right)+\frac{C_{u}}{2 D}(D-e)^{2}$ \\
\hline$(3)$ & $C_{u} \frac{e}{D} \leq N<C_{u}\left(1-\frac{e}{D}\right)$ & $M=\frac{D}{2} N\left(1-\frac{N}{C_{u}}\right)+P_{u}(D-2 e)$ \\
\hline$(4)$ & $C_{u} \frac{e}{D}-2 P_{u} \leq N<C_{u} \frac{e}{D}$ & $M=\left(N+2 P_{u}\right)\left(\frac{D}{2}-e\right)+\frac{C_{u} e^{2}}{2 D}$ \\
\hline$(5)$ & $-2 P_{u} \leq N<C_{u} \frac{e}{D}-2 P_{u}$ & $M=\frac{D}{2}\left(N+2 P_{u}\right)\left(1-\frac{N+2 P_{u}}{C_{u}}\right)$ \\
\hline
\end{tabular}

各部寸法を表す $B, D, e$ の定義は図 15 の通り

$P_{u}:$ 鋼管ダンパーの軸耐力

$C_{u}$ : コンクリート圧縮耐力 $\left(=f_{c} B D\right)$

$f_{c}$ : コンクリート圧縮応力のストレスブロックの強度

$P_{u} \cdot f_{c}$ の各段階の耐力算定用に以下のように設定する

\begin{tabular}{|c|c|c|}
\hline & $f_{c}$ & $P_{u}$ \\
\hline 降伏耐力算定時 & $2 F_{c} / 3$ & $n_{c} P_{y}$ \\
\hline 全塑性耐力算定時 & $0.85 F_{c}$ & $n\left(0.9{ }_{c} P_{\max }{ }_{c} P_{y}\right) / 2$ \\
\hline 最大耐力算定時 & $F_{c}$ & $n \times 0.9{ }_{c} P_{\max }$ \\
\hline
\end{tabular}

$n:$ 曲げ引張・圧縮側の片側の鋼管ダンパー本数

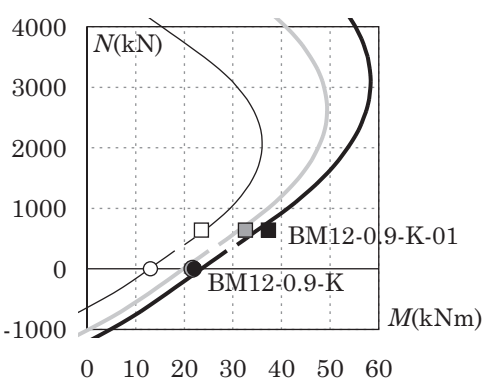

(a) BM12-0.9-K および BM12-0.9-K-0.1

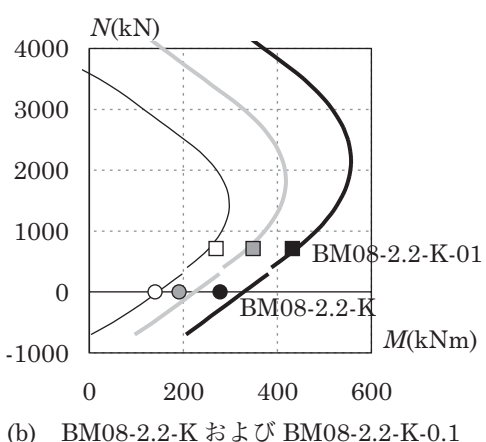

図 16 各耐力の実験值と計算式の比較 
表 9 弾性剛性実験值および計算值

\begin{tabular}{|c|c|c|c|c|c|c|}
\hline \multirow[b]{2}{*}{ 試験体 } & \multicolumn{4}{|l|}{ 実験值 } & \multirow{2}{*}{$\begin{array}{c}\text { 計算値 } \\
{ }_{c} K_{b} \\
(\mathrm{kN} / \mathrm{rad})\end{array}$} & \multirow{2}{*}{$\frac{{ }_{e} K_{b}}{{ }_{c} K_{b}}$} \\
\hline & $\begin{array}{c}N \\
(\mathrm{kN})\end{array}$ & $\begin{array}{c}P_{o} \\
(\mathrm{kN})\end{array}$ & $\begin{array}{c}M_{n} \\
(\mathrm{kNm})\end{array}$ & $\begin{array}{c}{ }_{e} K_{b} \\
(\mathrm{kN} / \mathrm{rad})\end{array}$ & & \\
\hline BM1209-K & 0 & 444.9 & 26.9 & 36900 & 35800 & 1.03 \\
\hline BM1209-K-01 & 640 & 29.5 & 97.7 & 47100 & 35800 & 1.32 \\
\hline BM0810-K & 0 & 36.2 & 21.7 & 39300 & 36100 & 1.09 \\
\hline BM0822-K & 0 & 33.3 & 20.0 & 34400 & 30600 & 1.12 \\
\hline BM0822-K-01 & 716 & 0.0 & 88.6 & 39000 & 30600 & 1.27 \\
\hline
\end{tabular}

概ね良く対応していることがわかる。

降伏曲げ耐力実験值 ${ }_{e} M_{y}$ は鋼管ダンパーが降伏した時点, 全塑性 曲げ耐力実験值 ${ }_{e} M_{p}$ は $M-\theta_{b}$ 関係における剛性が弾性剛性の $1 / 6$ と なった時点, 最大曲げ耐力実験值 ${ }_{e} M_{\max }$ は $M$ の最大值をそれぞれ正 側から採用している。曲げ耐力の $N-M$ 相関曲線（計算值）と実験 值の比較を図 16 に示す。これら実験值は $N-M$ 相関曲線と良い対応 を示している.

変形性能については, 既述の通り詳細な検討には至つていないも のの, シアキーを有する場合, 標準タイプで $0.035 \mathrm{rad}$ 以上, 高性能 タイプで $0.045 \mathrm{rad}$ 以上の柱脚回転角まで安定した紡鍾型（圧縮軸力 導入時はややくびれる）の履歴挙動を示す。また，亀裂発生後も一 時的な耐力低下やスリップ型・フラッグ型の履歴挙動への移行があ りつつも，概效耐力を保持することが確認できている，なお，大き な塑性変形が生じやすいと考えられているアンカーボルト先行降伏 型露出柱脚の必要変形性能として0.03rad を目安とする事例 10) を考 えると, 本システムの保有変形性能は, 実用に耐えうるものと期待 できる。しかしながら，本システムのような履歴性状を示す柱脚部 の必要変形性能については検討例がなく, 今後の検討課題である.

\section{5. まとめ}

本論では，露出柱脚に適用する鋼管ダンパーを開発するための基 礎的な検討として, 鋼管ダンパー単体の繰り返し軸方向載荷実験お よび鋼管ダンパーを適用した露出柱脚の載荷実験を実施した。

鋼管ダンパー単体の繰り返し軸方向載荷実験により, 径厚比が 8 〜 17 程度の比較的厚い断面を採用し, 大きな局部座屈変形を生じる 際の破壊性状について考察し, 以下の知見を得た。

・局部座屈発生後も大きな耐力上昇が生じ, 亀裂発生までは安定し た紡錘型の履歴性状を示すことが確認された。また，最大耐力に ついては, 既存の耐力式により, 概亦評価できる.

・ 局部座屈の座屈モードは, 長さ方向の中央に 1 つ局部座屈波が形 成される mode-Is, 非対称に 1 つ形成される mode-Ia, 2 つ形成 される mode-II に大別することができる.この局部座屈モードは, 局部座屈波長計算值 $l_{b}$ を基準にすることで, 判別が可能である.

・局部座屈や亀裂発生による早期の耐力低下を防ぐことで, 一定の 変形性能を確保する設計条件を 2 種類設定できる。すなわち, ダ ンパー部の端部では溶接せずに機械切削により加工し, 径厚比を 12 程度以下かつ長さを $1.2 l_{b} \sim 1.4 l_{b}$ とする標準タイプと, 径厚 比を 8 程度かつ長さを $2.6 l_{b}$ 程度とする高性能夕イプである.

鋼管ダンパーを適用した露出柱脚の載荷実験では, 上記の標準夕 イプと高性能タイプの鋼管ダンパーを対象とし, 本システムの実現 性について検討し, 以下の知見を得た。
・本システムを適用した露出柱脚は, 鋼管ダンパーに亀裂が発生す るまで，安定した紡錘型（圧縮軸力下ではややくびれる）の履歴 性状を示し, 亀裂発生後もスリップ型・フラッグ型に移行しなが ら概ね耐力を保持することが確認された。

・本システムを適用した露出柱脚の弾性剛性や曲げ耐力について は，既往の評価方法を援用することができる。

・本システムでは, 応力伝達機構の特性から, 軸力の大きさによっ ては, せん断抵抗要素としてベースプレート下面での摩擦力に期 待することができない. 摩擦力が生じない場合には鋼管ダンパー がせん断力を負担することとなり，早期に鋼管ダンパーに亀裂が 発生するものの, シアキーを適用することで, より高い変形性能 を確保することができる，すなわち，柱脚回転角の最大值で，標 準タイプでは $0.035 \mathrm{rad}$ 以上, 高性能タイプでは $0.045 \mathrm{rad}$ 以上 の変形性能を有している.

保有変形性能については, さらに詳細に検討する必要があるもの の, 以上の知見より, 本システムは, 露出柱脚に適用する履歴型夕゙ ンパーとして機能しうることが確認された. 本論の成果に基づいて, ダンパーとしての制振効果についても今後検討する必要がある.

\section{謝辞}

本研究は, 科学研究費補助金・若手研究 (B)「鋼構造露出柱脚に適 用する鋼管ダンパーの開発」および (社) 日本鉄鋼連盟「鋼構造研究・ 教育助成制度」(ともに, 代表: 向出静司・大阪大学) の助成を受け たものである、本研究を進めるにあたり, 大阪大学・甲津功夫名誉 教授および多田元英教授には, 貴重なご助言を頂いた。本実験の試 験体を製作するにあたり JFE シビル・森田時雄氏の助言・協力を得た. 本実験の一部は, 朝光拓也君 (元大阪大学) の卒業論文の一環とし て協力を得た。ここに記して謝意を表す。

\section{参考文献}

1) 桑原進, 山本訓久, 軸丸久司 : 柱脚にエネルギー吸収デバイスを挿入した 鋼構造骨組の地震応答性状に関する一考察 (その $1 \sim 2$ ), 日本建築学会大 会学術講演梗概集, C-1 分冊, pp.625-628, 2002.8

2) 緑川光正, 小豆畑達哉, 石原直, 和田章: 地震応答低減のためベースプレー トを浮き上がり降伏させた鉄骨架構の動的挙動, 日本建築学会構造系論文 集, NO.572, pp.97-104, 2003.10

3) 緑川光正, 長谷川達也, 石原直, 小豆畑達哉, 麻里哲広 : ロッキング架構 に用いる浮き上がり降伏ベースプレートの履歴特性と塑性変形能力, 日本 建築学会構造系論文集, NO.652, pp.1159-1166, 2010.6

4) 池永昌容, 長江拓也, 中島正愛, 吹田啓一郎 : 残留変形低減をめざした セルフセンタリング柱脚の開発と載荷実験, 日本建築学会構造系論文集, NO.612, pp.223-230, 2007.2

5) 九谷和秀, 増田貫志, 角屋治克 : 円筒形座金の変形能力を利用した鉄骨柱 脚部に関する研究, 日本建築学会大会学術講演梗概集, C-1 分冊, pp.783$784,2000.9$

6) Stephen P. Timoshenko, James M. Gere : Theory of Elastic Stability, Mac Graw-Hill Company, New York, pp.457-458, 1963

7）鈴木敏郎, 小河利行, 加藤征宏, 栗本照彦 : 軸圧縮を受ける高張力鋼管の 強度性状に関する研究，日本建築学会論文報告集，第 321 号, pp.28-37, 1982.11

8) 秋山宏 : 鉄骨柱脚の耐震設計, pp.20-30, 技報堂出版, 1985.3

9) 山西央朗, 玉井宏章, 高松隆夫, 松尾彰 : 露出柱脚の弾性回転剛性につい て ーアンカーボルト降伏先行型の場合-, 日本建築学会構造系論文集, 第 624 号, pp.317-324, 2008.2

10) 日本鋼構造協会 : 建築構造用アンカーボルトを用いた露出柱脚の設計施工 指針・同解説，2009.10 